\title{
Pengembangan Modul Analisis Vektor Terintegrasi Media Pembelajaran Prezi
}

\author{
Yunis Sulistyorini' ${ }^{1)}$, Dian Fitri Argarini' ${ }^{2)}$ \\ ${ }^{1,2)}$ IKIP Budi Utomo Malang \\ Email: yunis.sulistyorini@gmail.com,kejora.subuh14@gmail.com
}

\begin{abstract}
The study aims to describe the development and produce an integrated vector analysis module with Prezi that is valid, practical and effective. Development refers to the 4D development model, that is define, design, develop, and disseminate. Disseminate stage is not done in this research because the use of module is only limited to undergraduate students of Mathematics Education IKIP Budi Utomo Malang. The developed Vector Analysis module is feasible of use that satisfy all three aspects, namely validity, practicality and effectiveness. The developed vector analysis module has several advantages. First, connect the concept of vector analysis with real life. Second, integrated with prezi-based learning media that support deeper understanding of the concept of vector analysis.
\end{abstract}

Keyword: development, module, integrated, Prezi, Vector Analysis

\begin{abstract}
ABSTRAK
Penelitian bertujuan untuk mendeskripsikan pengembangan dan menghasilkan modul analisis vektor terintegrasi dengan media pembelajaran berbasis Prezi yang valid, praktis dan efektif. Pengembangan mengacu pada model pengembangan 4D, yaitu define, design, develop, dan disseminate. Tahap disseminate tidak dilakukan dalam penelitian ini karena penggunaan modul hanya terbatas pada mahasiswa Pendidikan Matematika IKIP Budi Utomo Malang. Modul Analisis Vektor yang dikembangkan layak digunakan yang memenuhi ketiga aspek, yaitu kevalidan, kepraktisan dan keefektifan. Modul analisis vektor yang dikembangkan mempunyai beberapa kelebihan. Pertama, menghubungkan konsep analisis vektor dengan kehidupan nyata. Kedua, terintegrasi dengan media pembelajaran berbasis Prezi yang mendukung pemahaman yang lebih mendalam terhadap konsep analisis vektor.
\end{abstract}

Kata Kunci: pengembangan, modul, terintegrasi, prezi, analisis vektor 


\section{PENDAHULUAN}

Analisis vektor merupakan salah satu matakuliah wajib bagi mahasiswa Pendidikan Matematika. Konsep dalam analisis vektor akan lebih mudah dipelajari jika didukung dengan visualisasi yang baik. Visualiasi dalam memahami konsep analisis vektor dapat diwujudkan dalam bahan ajar yang mendukung pembelajaran. Bahan ajar yang dikembangkan dalam penelitian ini adalah modul analisis vektor. Modul dipilih sebagai bahan ajar untuk pembelajaran analisis vektor dengan pertimbangan bahwa modul memungkinkan mahasiswa untuk lebih mandiri dalam pembelajaran. Hal ini sesuai dengan salah satu karakteristik modul yaitu self instruction (Pranata, dkk, 2016). Self instructional artinya peserta didik mampu membelajarkan diri sendiri atau tidak tergantung pada pihak lain.

Modul adalah suatu cara pengorganisasian materi pelajaran yang memperhatikan fungsi pendidikan dimana strategi pengorganiasian materi pembelajarannya terdiri dari tiga tahapan proses berpikir yaitu pembentukan konsep, interpretasi konsep dan aplikasi konsep (Indriyanti \& Susilowati, 2010). Pembentukan konsep dalam modul ini diwujudkan dengan penyajian definisi, sifat dan prinsip terkait analisis vektor. Interpretasi konsep dalam modul ini diwujudkan dalam ilustrasi yang mendukung konsep. Aplikasi konsep dalam modul ini diwujudkan dengan adanya contoh soal, latihan soal dan masalah dengan menerapkan konsep analisis vektor.

Secara khusus, interpretasi konsep dalam modul ini terintegrasi dengan media pembelajaran berbasis Prezi. Prezi merupakan aplikasi untuk presentasi online yang menyajikan berbagai pilihan dalam mengkreasikan dan menyimpan presentasi digital (Perron \& Stearns, 2010); dan prezi merupakan aplikasi yang mengkombinasikan berpikir kreatif dengan teknologi fasilitas yang modern (Spernjak, 2014). Prezi memiliki berbagai kelebihan dibandingkan aplikasi presentasi seperti PowerPoint. Peserta didik dengan pembelajaran yang menerapkan Prezi mempunyai kemampuan mengingat dan memahami yang lebih baik dibandingkan dengan pembelajaran yang merapkan PowerPoint (Akgun, dkk, 2016). Fox, dkk (2016) dan Strasser (2014) juga menyatakan bahwa siswa lebih menyukai pembelajaran dengan Prezi dibandingkan dengan PowerPoint. 
Selain untuk presentasi, prezi juga dapat digunakan sebagai alat untuk mengeksplorasi dan berbagi ide di atas kanvas virtual. Prezi menjadi unggul karena program ini menggunakan Zooming User Interface (ZUI), yang memungkinkan pengguna Prezi untuk memperbesar dan memperkecil tampilan media presentasi mereka. Keunikan presentasi dengan Prezi tidak perlu berpindah dari satu slide ke slide lain. Cukup dengan satu kanvas besar yang bisa disisipi gambar, video, data, dan lain-lain serta cukup digeser-geser saja maka jadilah tempat presentasi kita seperti melihat tampilan lukisan grafiti di dinding yang lebar. Jadi untuk presentasi dengan Prezi tak perlu banyak slide, cukup satu slide saja.

Prezi digunakan sebagai alat untuk membuat presentasi dalam bentuk linier maupun non-linier, yaitu presentasi terstruktur sebagai contoh dari presentasi linier, atau presentasi berbentuk peta-pikiran (mind-map) sebagai contoh dari presentasi non-linier. Pada Prezi, teks, gambar, video, dan media presentasi lainnya ditempatkan di atas kanvas presentasi, dan dapat dikelompokkan dalam bingkaibingkai yang telah disediakan. Pengguna kemudian menentukan ukuran relatif dan posisi antara semua obyek presentasi dan dapat mengitari serta menyorot obyekobyek tersebut. Untuk membuat presentasi linier, pengguna dapat membangun jalur navigasi presentasi yang telah ditentukan sebelumnya.

Interpretasi konsep yang terintegrasi dengan media pembelajaran berbasis Prezi diharapkan mampu membantu peserta didik memahami konsep analisis vektor. Penelitian bertujuan untuk mendeskripsikan pengembangan dan menghasilkan modul analisis vektor terintegrasi dengan media pembelajaran berbasis Prezi yang valid, praktis dan efektif.

\section{METODE PENELITIAN}

Penelitian ini ditujukan bagi mahasiswa program penelitian Pendidikan Matematika IKIP Budi Utomo Malang yang menempuh matakuliah Analisis Vektor. Lokasi dan subyek penelitian dipilih dengan pertimbangan bahwa mahasiswa masih kesulitan dalam memahami konsep Analisis Vektor dan belum adanya modul pembelajaran yang inovatif dan mendukung pembelajaran matakuliah tersebut. Hasil 
dari pengembangan media ini diharapkan mampu mempermudah dosen dan mahasiswa dalam pembelajaran matakuliah Analisis Vektor.

Pengembangan modul mengacu pada model pengembangan 4D. Model pengembangan 4D terdiri dari tahap define, design, develop, dan disseminate (Thiagarajan, dkk, 1974). Tahap disseminate tidak dilaksanakan dalam penelitian karena produk hanya terbatas penggunaannya pada mahasiswa program penelitian Pendidikan Matematika IKIP Budi Utomo Malang. Pada tahap define peneliti melakukan observasi dan melakukan wawancara pada dosen dan mahasiswa yang menempuh matakuliah Analisis Vektor. Pada tahap design, peneliti mengembangkan modul analisis vektor yang terintegrasi dengan media pembelajaran berbasis Prezi. Pada tahap develop, peneliti melakukan tahap validasi kepada ahli materi dan ujicoba produk. Hasil validasi dan ujicoba kemudian menjadi dasar untuk merevisi draft modul.

Instrumen yang dibutuhkan dalam penelitian ini adalah lembar validasi ahli materi, soal tes dan angket respon mahasiswa. (1) Lembar validasi ahli memuat penilaian dari ahli tentang kevalidan modul. Lembar validasi juga memuat saran dan komentar dari ahli sebagai bahan revisi modul yang dikembangkan. Validasi dilakukan pada validator ahli materi yaitu dosen pengampu matakuliah Analisis Vektor. (2) Angket respon mahasiswa digunakan untuk mengetahui kepraktisan modul pembelajaran ditinjau dari segi kelengkapan dan kemudahan penggunaan modul yang dikembangkan. (3) Soal tes digunakan untuk mengetahui keefektifan modul ditinjau dari pemahaman mahasiswa terhadap materi analisis vektor. Berikut ini adalah indikator penilaian dalam setiap aspek yaitu aspek kevalidan (BSNP, 2017), aspek kepraktisan dan keefektifan diadaptasi dari Zamzam (2013). 
Tabel 1. Indikator Aspek Kevalidan, Kepraktisan dan Keefektifan Modul

\begin{tabular}{|c|c|c|}
\hline Aspek & Instrumen & Indikator \\
\hline \multirow[t]{20}{*}{ Kevalidan } & \multirow{20}{*}{$\begin{array}{l}\text { Lembar } \\
\text { validasi } \\
\text { Ahli }\end{array}$} & Isi \\
\hline & & a. Cakupan materi \\
\hline & & b. Akurasi materi \\
\hline & & c. Merangsang keingintahuan \\
\hline & & Penyajian \\
\hline & & a. Teknik penyajian \\
\hline & & b. Pendukung penyajian materi \\
\hline & & c. Penyajian pembelajaran \\
\hline & & Kebahasaan \\
\hline & & $\begin{array}{ll}\text { a. Sesuai dengan perkembangan peserta } \\
\text { didik }\end{array}$ \\
\hline & & b. Komunikatif \\
\hline & & c. Lugas \\
\hline & & d. Koherensi dan keruntutan alur pikir \\
\hline & & e. Kesesuaian dengan kaidah Bahasa \\
\hline & & Indonesia yang benar \\
\hline & & $\begin{array}{ll}\text { f. Konsistensi penggunaan istilah dan } \\
\text { simbol/ lambang }\end{array}$ \\
\hline & & Kegrafikan \\
\hline & & a. Ukuran buku \\
\hline & & b. Bagian kulit buku \\
\hline & & c. Bagian isi buku \\
\hline \multirow[t]{2}{*}{ Kepraktisan } & \multirow{2}{*}{$\begin{array}{l}\text { Angket respon } \\
\text { mahasiswa }\end{array}$} & Kelengkapan bagian modul \\
\hline & & Kemudahan dalam menggunakan modul \\
\hline \multirow[t]{3}{*}{ Keefektifan } & \multirow[t]{3}{*}{ Soal tes } & Kemampuan mahasiswa dalam memahami \\
\hline & & konsep Analisis \\
\hline & & Vektor setelah menggunakan modul \\
\hline
\end{tabular}

Kelayakan modul yang dikembangkan ditinjau dari tiga aspek, yaitu kevalidan, kepraktisan dan keefektifan. Modul dikatakan valid jika rata-rata hasil validasi dari ahli materi minimal mencapai kriteria valid. Modul dikatakan praktis jika rata-rata penilaian berdasarkan angket respon mahasiswa minimal pada kriteria baik. Modul dikatakan efektif jika rata-rata hasil tes mahasiswa minimal pada kriteria baik. 


\section{HASIL DAN PEMBAHASAN}

Penelitian ini bertujuan untuk mendeskripsikan pengembangan dan menghasilkan modul analisis vektor yang terintegrasi dengan media pembelajaran berbasis Prezi yang valid, praktis dan efektif. Kevalidan modul ditinjau dari hasil validasi pada ahli materi, kepraktisan modul ditinjau dari hasil angket respon mahasiswa, dan keefektifan ditinjau dari hasil tes mahasiswa. Pengembangan modul mengacu pada model pengembangan 4D yang terdiri dari empat tahap, yaitu define, design, develop dan disseminate. Namun, tahap disseminate tidak dilakukan karena modul yang dikembangkan penggunaannya hanya terbatas pada mahasiswa program penelitian Pendidikan Matematika IKIP Budi Utomo Malang.

\section{Define}

Tahap define merupakan tahap awal dalam pengembangan modul. Pada tahap define dilakukan serangkaian kegiatan yaitu analisis tujuan awal, analisis siswa, analisis tugas, analisis konsep, dan perumusan tujuan pembelajaran. Serangkaian kegiatan tersebut dilakukan melalui observasi dan wawancara. Peneliti melakukan observasi dan melakukan wawancara pada dosen dan mahasiswa yang menempuh matakuliah Analisis Vektor. Melalui observasi dan wawancara diperoleh fakta bahwa belum ada bahan ajar inovatif yang mendukung pembelajaran matakuliah analisis vektor. Konsep dan tugas dalam matakuliah analisis vektor terdiri dari lima pokok bahasan, yaitu vektor dan skalar; hasil kali titik dan silang; diferensiasi vektor; gradient, divergensi dan curl; dan integrasi vektor. Tujuan atau capaian pembelajaran adalah mahasiswa mampu mengidentifikasi dan mengaplikasikan vektor untuk memecahkan permasalahan-permasalahan, khususnya dalam geometri.

\section{Design}

Pada tahap ini dilakukan perancangan modul yang dikembangkan. Langkahlangkah tahap perancangan ini adalah menyusun tes, memilih media, memilih format dan rancangan awal. Tes yang terdapat dalam modul meliputi konsep analisis vektor, yaitu vektor dan skalar; hasil kali titik dan silang; diferensiasi vektor; gradient, divergensi dan curl; dan integrasi vektor. Modul ini menggunakan format yang disesuaikan dengan kondisi mahasiswa. Modul dirancang dalam kertas ukuran B5 dengan ukuran font 11 . Penyusunan draft modul mengacu pada tahapan penyusunan 
bahan ajar menurut BSNP (2017). Diagram berikut ini menunjukkan tahapan pemilihan judul bab dan penyusunan draft modul.

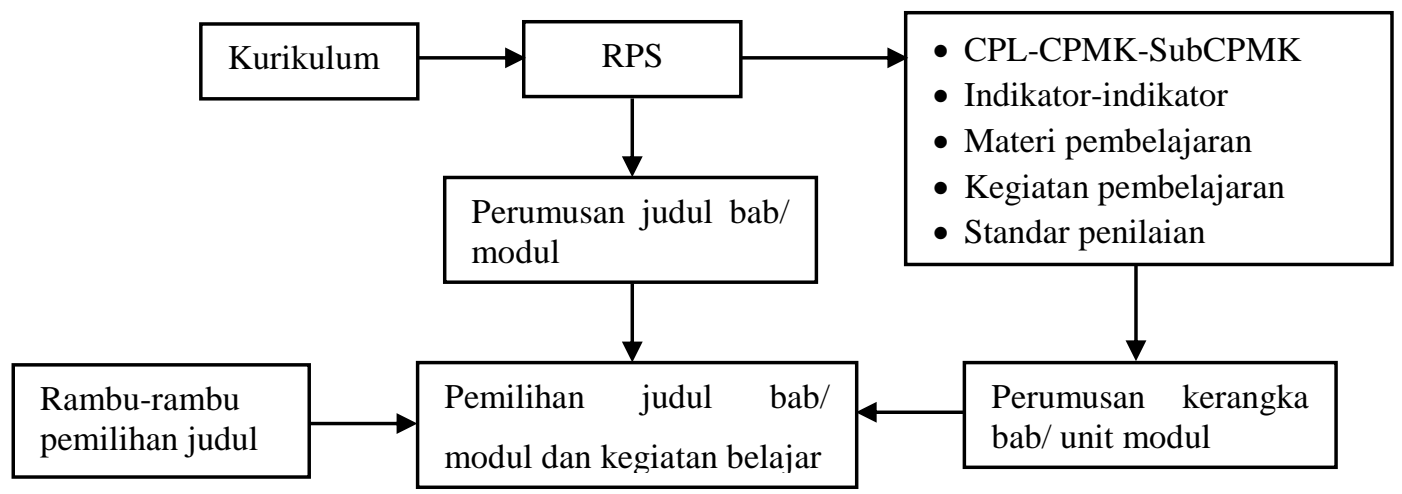

Gambar 1. Tahapan pemilhan judul bab (BSNP, 2017)

Modul analisis vektor terdiri dari lima judul berdasarkan pokok bahasan pada materi analisis vektor, yaitu modul vektor dan skalar; hasil kali titik dan silang; diferensiasi vektor; gradient, divergensi dan curl; dan integrasi vektor. Masingmasing pokok bahasan selanjutnya disusun draft modulnya dengan mengacu pada identifikasi dan elaborasi capaian pembelajaran, kecukupan materi dan kegiatan pembelajaran; identifikasi indikator dan penilaian; standar dan format penulisan dan rujukan-rujukan yang sesuai.

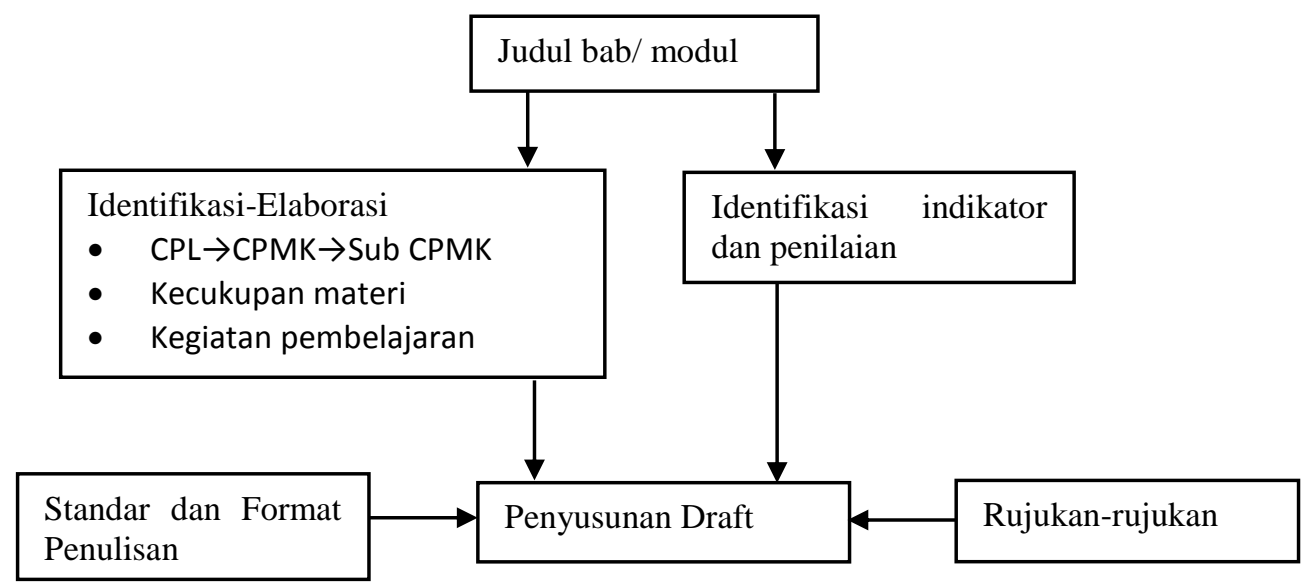

Gambar 2. Tahapan Penyusunan Draft (BSNP, 2017) 
Rancangan awal modul terdiri dari bagian pendahuluan, isi dan penutup.

\section{Bagian pendahuluan}

Bagian pendahuluan terdiri dari cover, kata pengantar, daftar isi, peta konsep dan petunjuk penggunaan modul. Pada bagian peta konsep, terdapat dua konsep yang harus dikuasai mahasiswa, yaitu vektor dan skalar; dan hasil kali dan silang agar mahasiswa dapat memahami konsep selanjutnya, yaitu diferensiasi vektor,; gradian, divergensi dan curl; dan integrasi vektor. Hal ini ditekankan kembali pada bagian petunjuk modul bahwa untuk dapat mempelajari suatu pokok bahasan mahasiswa harus mampu memahami konsep dalam pokok bahasan sebelumnya.
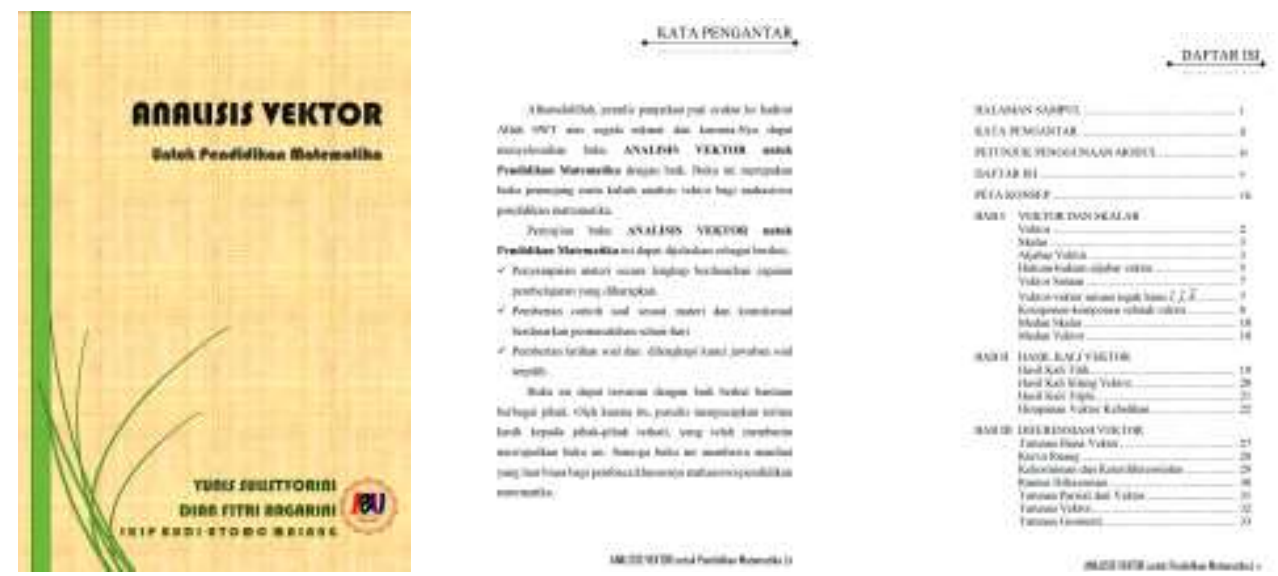

Gambar 3. Tampilan Cover Modul, Kata Pengantar dan Daftar Isi
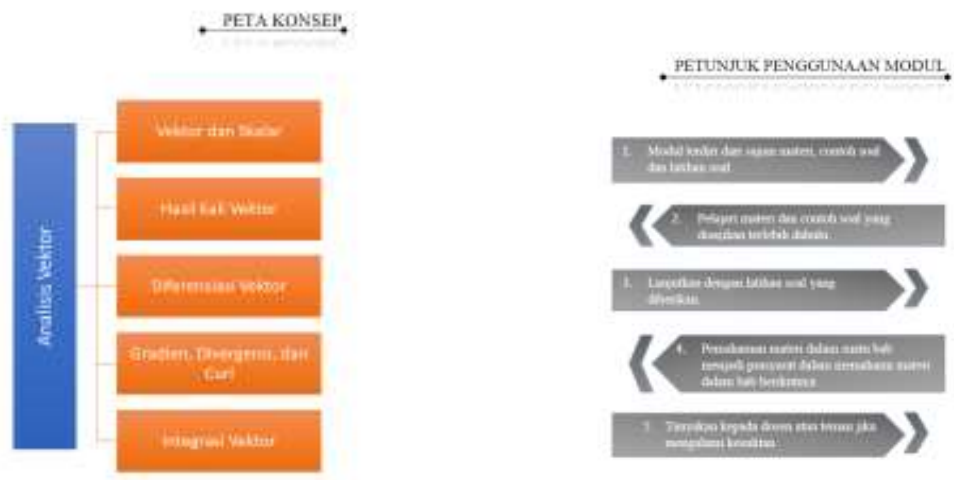

Gambar 4. Tampilan Peta Konsep dan Petunjuk Penggunaan Modul 


\section{Bagian isi}

Bagian isi terdiri dari sajian materi, contoh soal dan latihan soal. Pada bagian awal masing-masing pokok bahasan disajikan indikator-indikator yang diharapkan dikuasai mahasiswa setelah mempelajari modul tersebut. Indikatorindikator masing-masing pokok bahasan disajikan dalam Tabel 2 berikut ini.

Tabel 2. Indikator Pembelajaran Analisis Vektor

\begin{tabular}{|c|c|c|}
\hline No & Pokok Bahasan & Indikator \\
\hline \multirow[t]{4}{*}{1.} & Vektor dan skalar & 1.1 Menemukan definisi vektor dan skalar \\
\hline & & 1.2 Membedakan vektor dan skalar \\
\hline & & $\begin{array}{l}\text { 1.3 Mengaplikasikan vektor dan skalar pada geometri } \\
\text { dan fisika }\end{array}$ \\
\hline & & 1.4 Menyusun persamaan vektor garis lurus \\
\hline \multirow[t]{4}{*}{2.} & Hasil kali titik dan silang & $\begin{array}{l}\text { 2.1 Menghitung hasil kali titik dan silang dari dua } \\
\text { vector }\end{array}$ \\
\hline & & 2.2 Menghitung hasil kali triple vektor \\
\hline & & 2.3 Membedakan hasil titik dan silang \\
\hline & & 2.5 Mengaplikasikan hasil kali vektor pada geometri \\
\hline \multirow[t]{5}{*}{3.} & Diferensiasi vektor & 3.1 Mendeskripsikan derivatif fungsi vektor \\
\hline & & $\begin{array}{l}\text { 3.2 Menyatakan titik dari kurva ruang dengan vektor } \\
\text { posisi }\end{array}$ \\
\hline & & 3.3 Menentukan vektor tangent \\
\hline & & $\begin{array}{l}\text { 3.4 Menyebutkan syarat-syarat kontinuitas dan } \\
\text { diferensiabilitas fungsi vektor }\end{array}$ \\
\hline & & 3.5 Menentukan derivatif parsial \\
\hline \multirow[t]{4}{*}{4.} & $\begin{array}{l}\text { Gradien, divergensi dan } \\
\text { curl }\end{array}$ & 4.1 Menggunakan operator diferensial \\
\hline & & $\begin{array}{l}\text { 4.2 Menentukan gradien fungsi scalar dan derivatif } \\
\text { arah }\end{array}$ \\
\hline & & 4.3 Menentukan divergen fungsi vektor \\
\hline & & 4.4 Menentukan curl medan vektor \\
\hline \multirow[t]{4}{*}{5.} & Integrasi vektor & 5.1 Menghitung integral biasa \\
\hline & & 5.2 Menghitung integral garis \\
\hline & & 5.3 Menghitung integral luas \\
\hline & & 5.4 Menghitung integral volume \\
\hline
\end{tabular}

Pada bagian isi disajikan berbagai konsep analisis vektor yang dibagi menjadi lima pokok bahasan. Selain itu, juga disajikan hubungan antara konsep analisis vektor dengan kehidupan nyata, terutama dengan fisika. Penyajian ini diharapkan mampu membantu mahasiswa untuk memahami konsep analisis vektor denga lebih menyeluruh karena melibatkan kehidupan nyata dalam pembelajaran. 


\section{BAB 1 \\ VEKTOR DAN SKALAR}

\section{MATERI-MATERI}

\section{- VEKTOR}

Adalah besaran yang menapurya besar dan arah. Contoh dan besann vektor antara bin yain perpindahan (displaconowe), kecepatan, gaya, dan percepatan.

Secan gmafis, vektor digambarkan oleh sebuah anak panah $O P$ (bisa dilihat poda Gamabar 1) yang mendefizusikan arahnya sedangkan besarnya dinyatakan oleh panjang anak parah. Ujung pangkal $O$ dan anak parah disebut tink pargkal vektor dan ujung kepala $P$ disebut nak ujung.

Gambar 5. Tampilan Sajian Materi

\section{LATHANSOAL}

1. $\operatorname{ska} \vec{R}(u)=\left(u-u^{2}\right) \vec{\lambda}+2 u^{3} \vec{j}-3 \vec{k}$, teutikan $\int \vec{R}(u) d u$ $d m \int_{1}^{2} \vec{R}(u) d u$.

2. Jika $\vec{A}=\left(3 x^{2}+6 y\right) \vec{t}-14 y z \vec{j}+20 x z^{2} \vec{k}$, hitueglah If $\vec{A} \cdot d r$ dan $(0,0,0)$ ke $(1,1,1)$ sepanjang lintasasIntasan $C$ yatu $x=t, y=t^{2}, z=t^{3}$

3. Cari ushta tocal yang dilhkukan untuk toenggerskkan sobuah partikel dalnat medan gaya yang ditberikan oleh $\vec{F}=3 x y \hat{i}-5 z \hat{j}+10 x \vec{k}$ sepamjang kurva $x=t^{2}+$ 1, $y=2 t^{2}, z=t^{3}$ dan $t=1$ tinges $t=2$.

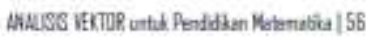

Gambar 6. Tampilan Latihan Soal

\section{Bagian penutup}

Bagian penutup terdiri dari kunci jawaban untuk soal terpilih, daftar pustaka dan profil penulis.

\section{KUSCI JAWABAN SOAL TERPILIH}

B.AB I

1. Shathr dan Vesiter

\begin{tabular}{|c|c|}
\hline a. skaler & 8 \\
\hline b. Vodiar & h. \\
\hline c. Sklaba & 2 \\
\hline d. Skabur & t \\
\hline e. Skalar & $k$ \\
\hline f Skatrr & I \\
\hline
\end{tabular}

CATATAN

$\stackrel{\bullet}{\longrightarrow}$

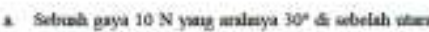
deri timur

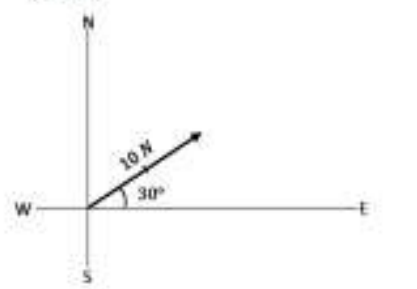

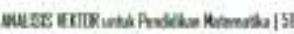

Gambar 7. Tampilan Kunci Jawaban 


\section{Develop}

Pada tahap ini dilakukan tahap pengubahan rancangan dasar modul hingga mencapai versi akhir untuk digunakan. Pada tahap develop, modul yang sudah dikembangkan divalidasi pada dua dosen Pendidikan Matematika IKIP Budi Utomo Malang yang membina matakuliah analisis vektor. Dari hasil validasi terhadap dua dosen validator diperoleh data berikut ini. Hasil validasi dari dua ahli materi diperoleh rata-rata 3,86 yang berada pada kriteria sangat baik. Berdasarkan hasil penilaian tersebut maka modul yang dikembangkan dapat dikatakan valid.

Tabel 3. Hasil Validasi Ahli Materi

\begin{tabular}{|l|c|l|}
\hline Validator & Penilaian & Keterangan \\
\hline Dosen 1 & 3,89 & Sangat baik \\
\hline Dosen 2 & 3,82 & Sangat baik \\
\hline
\end{tabular}

Selain itu, dari hasil validasi ahli materi diperoleh saran dan kritik untuk perbaikan modul yang dikembangkan. Saran yang pertama terkait dengan kurangnya soal-soal yang berkaitan dengan materi. Saran yang kedua terkait dengan format penulisan untuk lebih menekankan bagian yang penting. Saran yang ketiga tekait dengan pemilihan warna pada Petunjuk Penggunaan Modul.

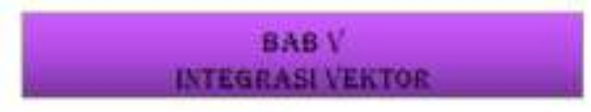

\section{MATERI-MATERI}

- NTEGRAL BLASA DARI VEKTOR

Misalkan $\vec{R}(u)=R_{1}(u) i+R_{2}(u) j+R_{3}(u) k$ setnuah

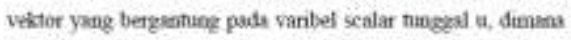
$R_{1}(u), R_{2}(u), R_{2}(u)$ koutim delim suatu selang yang ditentukam Maka

Gambar 8a. Tampilan Sebelum Revisi

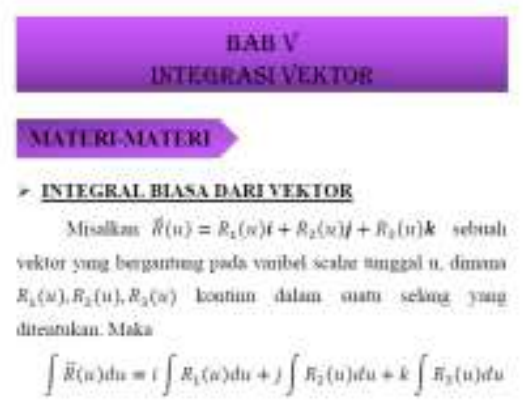

Gambar 8b. Tampilan Setelah Revisi

Saran yang pertama diperbaiki dengan menambah lebih banyak lagi soalsoal yang berkaitan dengan materi. Sedangkan saran yang kedua diperbaiki dengan memberikan garis bawah pada judul subbab untuk menekankan bagian yang penting dalam modul. Saran yang ketiga diperbaiki dengan memilih warna yang lebih beragam dalam penulisan Petunjuk Penggunaan Modul. 


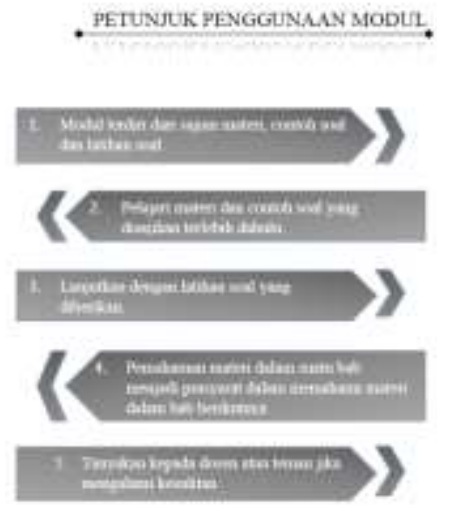

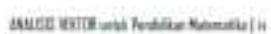

Gambar 9a. Tampilan Sebelum Revisi

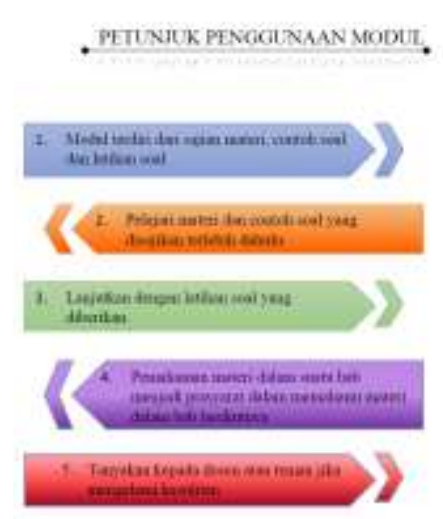

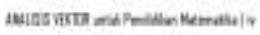

Gambar 9b. Tampilan Sesudah Revisi

Pada tahap develop juga dilakukan pemberian angket respon mahasiswa. Secara terperinci aspek kepraktisan ini ditinjau dari dua indikator, yaitu kelengkapan bagian modul dan kemudahan dalam menggunakan modul. Dari indikator kelengkapan bagian modul diperoleh rata-rata penilaian dari mahasiswa yaitu 2.87 (kriteria baik) sedangkan dari indikator kemudahan dalam menggunakan modul diperoleh rata-rata penilaian dari mahasiswa yaitu 3,17 (kriteria sangat baik). Dari kedua indikator diperoleh rata-rata penilaian kepraktisan modul adalah 3,02 (kriteria baik). Berdasarkan hasil penilaian tersebut maka modul yang dikembangkan dapat dikatakan praktis.

Selain validasi dan pemberian angket respon mahasiswa, pada tahap develop juga dilakukan pemberian tes kepada mahasiswa. Tes diberikan setelah mahasiswa menggunakan modul. Rata-rata hasil tes mahasiswa adalah 80, 67 yang berada pada kriteria baik. Berdasarkan hasil penilaian tersebut modul yang dikembangkan dapat dikatakan efektif. Berdasarkan hasil analisis data diperoleh bahwa modul yang dikembangkan layak digunakan dalam pembelajaran Analisis Vektor bagi mahasiswa Pendidikan Matematika IKIP Budi Utomo Malang. Modul yang layak ini memenuhi ketiga aspek, yaitu valid, praktis dan efektif.

Modul analisis vektor yang dikembangkan mempunyai beberapa kelebihan. Pertama, menghubungkan konsep analisis vektor dengan kehidupan nyata. Analisis 
vektor sangat berhubungan erat dengan kehidupan nyata. Salah satu contoh besaran vektor adalah gaya, berat, kecepatan, momentum, intensitas medan magnet, tegangan dan gaya sentrifugal. Koneksi dengan kehidupan nyata dapat meningkatkan baik motivasi peserta didik maupun pemahaman dan kemampuan pemecahan masalah (Karakoc \& Alacaci, 2015). Oleh karena itu menghubungkan konsep analisis vektor dengan kehidupan sehari-hari memberikan banyak manfaat bagi mahasiswa.

Salah satu hubungannya adalah dengan konsep fisika dalam kehidupan sehari-hari. Fisika yang merupakan ilmu sains sangat berhubungan erat dengan matematika. Bahkan, School Science and Mathematics Association, National Council of Teachers of Mathematics (NCTM), American Association for the Advancement of Science dan National Research Council (NRC) menyarankan adanya integrasi antara matematika dan sains dalam pembelajaran (Bossé, dkk, 2010). Ekspetasi dari NCTM terkait dengan integrasi antara matematika dan sains dalam pembelajaran adalah peserta didik mampu meningkatkan pemahaman matematis (Sherrod, dkk, 2009). Sedangkan ekspetasi dari National Science Education Standards adalah peserta didik terlibat baik dalam penyelidikan dan diskusi maupun asesmen yang mendorong peserta didik untuk menganalisis temuannya dan mengorganisasi kesimpulan (Sherrod, dkk, 2009). Pembelajaran dengan mengintegrasikan matematika dan sains memberikan dampak positif bagi peserta didik (Arnett \& Van Horn, 2009).

Kedua, terintegrasi dengan media pembelajaran berbasis Prezi. Media pembelajaran berbasis Prezi merupakan bahan ajar berbentuk video pembelajaran yang inovatif. Video pembelajaran terdiri dari lima bagian disesuaikan dengan konsep analisis vektor yang dipelajari oleh mahasiswa, yaitu vektor dan skalar, hasil kali titik dan silang, diferensiasi vektor, gradient, divergensi dan curl, dan integrasi vektor. Video pembelajaran tersebut membantu mahasiswa memvisualisasikan konsep analisis vektor yang dipelajari. 

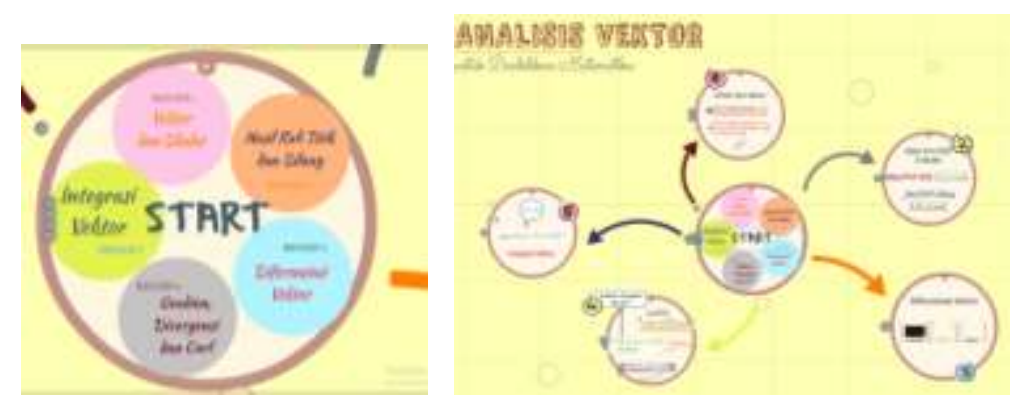

Gambar 10. Tampilan Dalam Media

Modul yang dikembangkan menjadi pendamping dari video pembelajaran tersebut. Modul ini lebih terperinci untuk mendukung pemahaman yang lebih mendalam terhadap konsep analisis vektor. Sebagai contoh pada Gambar 10 ditunjukkan tampilan peta konsep untuk analisis vektor yang disajikan dalam modul seperti pada Gambar 4. Contoh yang lain adalah dalam penjabaran konsep turunan biasa. Dalam media Prezi disajikan visualisasi konsep turunan biasa sedangkan pada modul disajikan penjabaran yang lebih mendalam terkait konsep turunan biasa.

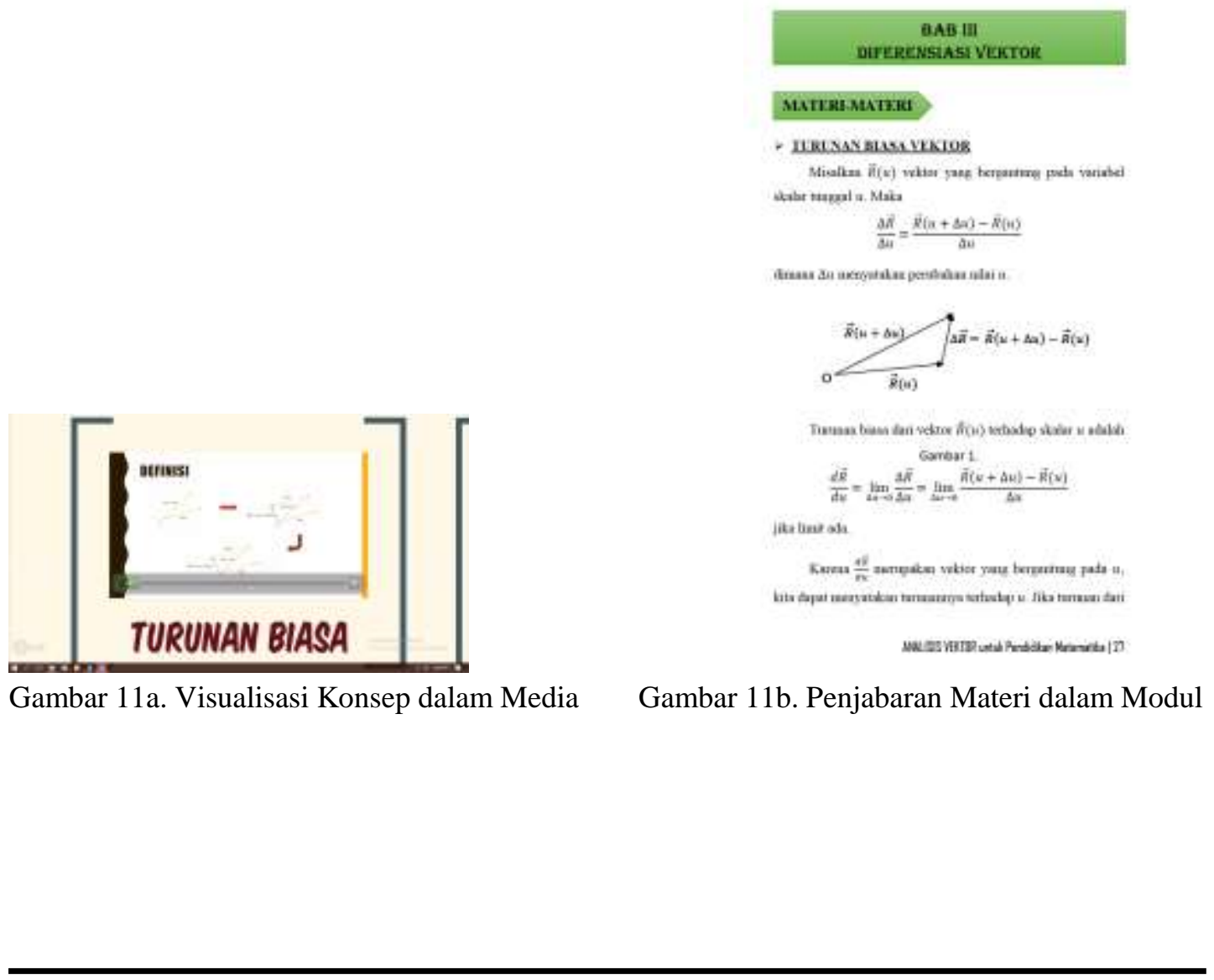




\section{KESIMPULAN DAN SARAN}

Modul Analisis Vektor yang dikembangkan layak digunakan dalam pembelajaran Analisis Vektor bagi mahasiswa Pendidikan Matematika IKIP Budi Utomo Malang. Modul yang layak ini memenuhi ketiga aspek, yaitu valid, praktis dan efektif. Aspek kevalidan diperoleh dari hasil validasi ahli materi yang berada pada kategori valid dengan rata-rata penilaian 3,86. Aspek kepraktisan diperoleh dari hasil angket respon mahasiswa yang berada pada kategori baik dengan rata-rata penilaian 3,02. Aspek keefektifan diperoleh dari hasil tes mahasiswa yang berada pada kategori baik dengan rata-rata hasil tes 80,67 . Modul analisis vektor yang dikembangkan mempunyai beberapa kelebihan. Pertama, menghubungkan konsep analisis vektor dengan kehidupan nyata. Kedua, terintegrasi dengan media pembelajaran berbasis Prezi yang mendukung pemahaman yang lebih mendalam terhadap konsep analisis vektor.

Untuk penelitian selanjutnya dapat dikembangkan bahan ajar yang lebih inovatif untuk mendukung pembelajaran Analisis Vektor maupun pembelajaran matakuliah lainnya.

\section{REFERENSI}

Akgun, Ozcan E., Babur, Aslihan \& Albayrak, Ebru. 2016. Effects of Lectures with PowerPoint or Prezi Presentations on Cognitive Load, Recall, and Conceptual Learning. International Online Journal of Educational Sciences, 8 (3): 1-11.

Arnett A, \& Van Horn D. 2009. Connecting Mathematics and Science: A Learning Community that Helps Math-Phobic Students. Journal of College Science Teaching, 38 (6): 30-34

Bossé, M, Lee, T, Swinson M, Faulconer J. 2010. The NCTM Process Standards and the Five Es of Science: Connecting Math and Science. School Science and Mathematics, 110 (5): 262-276.

BSNP. 2017. Panduan Penyusunan Perangkat Pembelajaran dan Bahan Ajar. Kementerian Riset, Teknologi dan Pendidikan Tinggi Direktorat Jenderal Pembelajaran dan Kemahasiswaan Direktorat Pembelajaran.

Fox, H., Worasuwankumutinee, Werwe, J.W., \& Metcher, R. 2016. Prezi Versus Powerpoint in the Classroom. Makalah disajikan dalam Proceeding of 63th The International Conference, Phuket, Thailand, 28 Februari. 
Indriyanti, N. Y. \& Susilowati, E. 2010. Pengembangan Modul. Makalah disajikan dalam Pelatihan Pembuatan e-module bagi Guru-guru IPA Biologi SMP seKota Surakarta menuju Open Education Resources, Surakarta, 7 Agustus.

Karakoc, G. \& Alacaci, C. 2015. Real World Connection in High School Mathematics Curriculum and Teaching. Turkish Journal of Computer and Mathematics Education, 6 (1): 31-46.

Perron, Brian E. \& Stearns, Alyson G. 2010. A Review of a Presentation Technology: Prezi. Research on Social Work Practice, 000 (00): 1-2.

Pranata, B. D., Mahanal, S. \& Lestari, U. 2016. Pengembangan Modul Pembelajaran Biologi Berbasis Discovery Inquiry pada Materi Sistem Reproduksi untuk Siswa Kelas IX SMA. (online), http://jurnalonline.um.ac.id/data/artikel/artikelCB9E73E11E37D421CAA279D4216CF 6DD.pdf. Diakses 7 November 2017.

Sherrod, S. E., Dwyer, J. \& Narayan, R. 2009. Developing Science and Math Integrated Activities for Middle School Students. International Journal of Mathematical Education in Science and Technology, 40 (2): 247-257.

Spernjak, A. 2014. Is Prezi More Usefullness Education Tool Than PowerPoint. Makalah disajikan dalam International Conference on Education in Mathematics, Science and Technology, Turki, 16-18 Mei.

Spiegel, Murray R. 1959. Schaum's Outline of Theory and Problems of Vector Analysis and an Introduction to Tensor Analysis. USA: McGraw-Hill, Inc.

Spigel, Murray R. 1981. Vector Analysis. McGraw-Hill, Inc.

Strasser, N. 2014. Using Prezi in Higher Eduaction. Journal of College Teaching \& Learning, Second Quarter, 11 (2).

Thiagarajan, S., Semmel, D. S., \& Semmel, M. I. 1974. Instructional Development for Training Teachers of Expectional Children. Minnesota.

Zamzam, K. F. 2013. Pengembangan Modul Pembelajaran Matematika dengan Pendekatan PBL pada Materi Segitiga dan Jajargenjang Siswa Kelas IV $S D$. Tesis tidak diterbitkan. Malang: Program Pascasarjana Universitas Negeri Malang. 